\title{
Governmental Measures towards the Coronavirus Crisis Management: An Applied Study from the Viewpoint of Faculty Members in Jordanian Universities
}

\author{
Dr. Abdalhaleem Manaa Aladwan ${ }^{1}$ \\ ${ }^{1}$ Dean of the College of Islamic Arts, The World Islamic Sciences and Education University, Jordan \\ Correspondence: Dr. Abdalhaleem Manaa Aladwan, World Islamic Sciences and Education University, Dean of \\ the College of Islamic Arts, Jordan.
}

Received: May 7, 2020

Accepted: May 21, 2020

Online Published: May 22, 2020

doi:10.5539/mas.v14n6p64

URL: https://doi.org/10.5539/mas.v14n6p64

\begin{abstract}
This study is considered one of the rare studios in the world that examine the effect of government measures towards managing the Coronavirus crisis, according to the researcher's knowledge, the study relied on the descriptive-analytical approach, as well as on interviews with those in charge of crisis management in Jordan, (254) questionnaires were obtained from the study population sample, the Sampling unit was represented by faculty members in the departments of political science, media, and economics in Jordanian universities. The study reached the following: the high level of government measure implementation in the face of the Corona crisis, that the level of corona crisis management was moderate, and the effect of governmental measures on the management of the Corona crisis is an applied study from the viewpoint of faculty members in Jordanian universities. The study recommended the development of comprehensive visual and written media programs to educate citizens about the risk of disease, intensify health measures through preventive tracking teams for early detection of cases, that security measures not be at the expense of public freedoms, and find solutions to current and expected economic problems due to the crisis.
\end{abstract}

Keywords: governmental measures, corona virus crisis management, Jordan, faculty members in Jordanian universities

\section{Introduction}

The history of epidemics has had a major impact on the behavior of affected countries and societies, since the outbreak of the Coronavirus (Covid-19) in China in December 2019, and then spread to various parts of the world, (Chen, Yang, Yang, Wang, 2020). Coronaviruses are a large group of viruses that may cause disease in animals and humans, it is known that a large number of coronaviruses cause in humans respiratory infections that range from common colds to more severe diseases, especially such as Middle Eastern respiratory syndrome and severe acute respiratory syndrome (SARS), The newly discovered Coronavirus causes Coronavirus disease Covid-19 (Coronavirus Covid-19, 2020. p4.).Countries have responded to the pandemic, and while models of countries facing the epidemic have been praised, such as China, South Korea, Singapore, Taiwan, and Sweden, however, the distinctive Arab models were not highlighted in managing the crisis facing Corona, the most prominent of which is the model of the Hashemite Kingdom of Jordan (Al-Maani, 2020). As for crisis management, this means the art of dealing with the crisis, which is the decision-making process under abnormal circumstances, or is it how to overcome the crisis with different scientific and administrative tools and avoid its negatives and benefit from its positives and at the state level, the crisis management means raising the efficiency and capacity of the decision-making system at the individual and collective levels, politically, it means manipulating elements of the situation, including waving the use of force in a manner that guarantees national interests (Al-Zubaidi, 2010). The strategy pursued by the Hashemite Kingdom of Jordan in managing the Corona crisis has significantly reduced the spread of the Coronavirus disease; although the population of about 9 million people and the society in Jordan is characterized by tremendous diversity, and the state is open and globalized, however, the number of injuries does not exceed 445 individuals, and deaths are only 7 (as of April 28), which means that the death rate in the country is less than $1 \%$, it is a rate that is much less than the Arab average $4 \%$ and the global average which is $6 \%$, the recovery rate in Jordan is $55 \%$ of the recorded cases compared to the 
Arab rate of $21 \%$ and $23 \%$ at the global level, and this indicates the care and efficiency of the medical system in Jordan (Al-Abadi, 2020).

\section{The Problem of the Study}

The Corona crisis is a global and local crisis, and this crisis can only be faced with rational management by the state, the Jordanian government has given all importance to managing this crisis and has taken a number of measures including (health measures, media measures, security measures, economic measures) in order to manage this crisis, these measures have proven success and the work is still going on, and the state has recruited all its capabilities to do so, however, some of these measures face negative reactions from citizens because they feel that they are restricting their freedom and stopping their economic activity. It was necessary to go to the experts from the faculty members in the Jordanian universities in the field of politics, media, and economics and take their opinion through a questionnaire distributed to them, and interviewing those in charge of managing the crisis in the state apparatus. All this in order to know the role of government measures in managing the crisis through its indicators in the following aspects (discovering early warning signs, preparedness, and prevention to face the crisis, containment of damages, restoration of normal activity, coordination with other countries in disease control).

\section{Objectives of the Study}

- $\quad$ Learn about the governmental measures taken by the government to manage the Coronavirus crisis and from the viewpoint of faculty members in Jordanian universities.

- $\quad$ Learn about the reality and level of the state administration of the Coronavirus crisis from the viewpoint of faculty members.

- $\quad$ Learn about the impact of government measures in reducing the Corona crisis and from the viewpoint of faculty members.

\section{The Importance of the Study}

The importance of the study stems from the identification of the government measure against the Coronavirus, and the extent of the success of these measures in practice in surrounding the virus and reducing its health, economic and security effects on Jordanian society, and stand on the negative effects of these measures, especially those related to restricting the freedoms of citizens, in light of the issuance of a set of defense laws and the disruption of natural law, and provide the decision-maker with the results that can be reached in order to overcome the effects of the current and future crisis.

\section{Study Hypothesis}

\section{The main hypothesis}

There is no statistically significant effect at the level of $(\alpha \leq 0.05)$ of government measures with its dimensions (health measures, media measures, Security and political measures, economic measures) on the management of the Coronavirus crisis from the viewpoint of faculty members in Jordanian universities.

\section{The main hypothesis is divided into the following sub-hypotheses}

- There was is no statistically significant effect at $(\alpha \leq 0.05)$ of the health measures on managing the Coronavirus crisis from the viewpoint of faculty members in Jordanian universities.

- $\quad$ There is no statistically significant effect at $(\alpha \leq 0.05)$ of the media measures on managing the Coronavirus Crisis from the viewpoint of faculty members in Jordanian universities.

- $\quad$ There is no statistically significant effect at the level of $(\alpha \leq 0.05)$ of the Security and political measures on managing the Coronavirus Crisis from the viewpoint of faculty members in Jordanian universities.

- There is no statistically significant effect at $(\alpha \leq 0.05)$ of the economic measures on the management of the Coronavirus Crisis from the viewpoint of faculty members in Jordanian universities.

\section{A Review of the Previous Literature}

\subsection{Governmental Measures}

The Jordanian model in dealing with the Corona pandemic is one of the most successful experiences in the world, despite the humility of national capabilities and economic resources, and by the testimony of many international institutions and opinion leaders around the world, a package of early precautions has been adopted to contain the virus from closing borders and closing unnecessary stores. The government also used a gradual method to contain the emerging epidemic crisis represented by all its executive arms, and a careful study of international 
practices on the extent of the disease, within an integrated system of procedures characterized by complementarity, flexibility, and impartiality, according to the reality of the local and international situation related to the epidemic, where the main objective of the series of measures and decisions taken was to provide a system of health, economic, social, and developmental protection aimed at containing internal and external threats to the Kingdom's health security, and finding ways to address them (Al-Hawyan, 2020) (Assaf \& Alsawalhah, 2013). Transmission of COVID-19 is much more transmissible than SARS, and the mortality rate in cases $(2.3 \%)$ is much higher than the seasonal flu rate (China CDC Weekly. 2020; 2: 113-22.). The uncertain incubation period of the virus and its potential transmission without symptoms causes more fear and anxiety, and that the governments reducing the severity of the epidemic undermined public confidence in the transparency and efficiency of government decision-making, and the unprecedented measures of quarantine on a large scale in all countries of the world, which dictate that people stay in their homes, have a negative psycho-social impact on them (Brooks, 2020). The Jordanian government has taken several measures and decisions aimed at controlling the spread of the emerging coronavirus, the first case of which appeared at the beginning of last January 2020, the number of confirmed cases exceeded 390, including 7 deaths, as a result of infection by the virus, to April 2020.

\subsubsection{The Dimensions of Government Measures}

\section{First: Health Measures}

The government has taken strict measures and preventive measures to contain the disease and not to spread it, by developing procedures to monitor cases at entry points into the territory of the state, promote proactive case detection by expanding laboratory tests, and providing specialized and appropriate quarantine places and appropriate treatment protocols for cases, as well as active tracking of contacts, as well as taking standard measures to reduce disease transmissions, such as disrupting educational institutions, suspending air traffic to and from the country, stopping all public activities, preventing gatherings, and closing public places such as shopping centers and parks. And also an attempt not to disrupt the normal lives of people, despite the implementation of "social divergence" measures and the launch of the "Stay Home" campaign, that urges people to stay in their homes and not go out except for necessity, except that the state took into account the mental health of individuals, so I followed the gradual approach in the procedures for limiting the movement of people, applying the partial ban from six in the evening until ten in the morning (Al-Maani, 2020).

\section{Second: Media Measures}

In this type of crisis, the media participates with government agencies in a major role in managing them through several major tasks, represented in (Shield Al-Watan Magazine, 2020):

- The link: to play the role of the link between the authorities concerned with managing the crisis and the members of society, and to clarify the nature of the actions taken by these bodies, with all transparency and clarity, in order to prevent any ambiguities or false interpretations of the truth, as the media in this context publishes information about any crisis or disaster in a transparent and accurate manner, and transmits it to members of society in a clear, simple and understandable message, it enables them to know the crisis in its various dimensions, and realize its risks and challenges and how to deal with it. This role depends mainly on the nature of the information provided by government agencies involved in the crisis, whenever it allowed information to flow in a transparent manner, it helped the media to play its role, while the absence of information leads to the emergence of rumors about the crisis, which may hinder government efforts in managing the crisis.

- The Educational role: There is no doubt that the role of the various media organizations, visual, audio and read, in their role in educating members of society is of great importance, it is not just about educating them in ways to face crises and how to work to contain their various effects and repercussions, but also, and perhaps most importantly, their involvement in the crisis management process, based on the premise that the success of managing any crisis requires the integration of all efforts in it, the governmental and societal, and here the media plays a vital and major role in promoting the idea of integrating social responsibility in crisis management.

The preventive role: The effectiveness of the media's role is no longer measured by its educational and informational role only, but also by the initiatives and campaigns that aim to enhance the protection of society in times of crisis, the media, with its various platforms and activities, like programs that host experts and specialists, and shedding light on countries' experiences in dealing with crises, it contributes to protecting members of society.

- Addressing rumors: which aims to create chaos at home and threaten social cohesion, and the role that the media plays in this regard is very important, especially if taking into account the fact that rumors are booming 
and spreading rapidly in times of crisis, people resort to believing it, especially if the parties involved in the crisis do not provide information about it and provide it to the various media. Mostly, the source of these rumors is social media platforms that are not subject to regulations governing their work.

\section{Third: Security and political measures}

The government suspended civil laws and issued a package of defense laws, giving the government "absolute powers," and freezes existing laws and puts them in the hands of the Prime Minister personally to manage state affairs during this difficult period, "according to legal experts. The Jordanian King Abdullah II stipulated that the application of the Defense Law and the orders issued pursuant thereto should be in the narrowest possible scope, in a manner that does not affect and safeguard the political and civil rights of Jordanians, and protects public freedoms and the right to expression guaranteed by the constitution and within the framework of the ordinary laws in force, and ensuring respect for private property, whether real estate, movable or immovable property, from his part, Jordanian Prime Minister Omar Al-Razzaz stated that the activation of the defense law came because of an exceptional circumstance that required providing an instrument for the government, and an additional way to protect public health and preserve the safety of citizens, stressing that the right to life and the health of Jordanians is sacred, which is advanced over all other rights. (Majid, 2020).

\section{Fourth: Economic Measures}

Regarding the economic effects of coronavirus spread, there are some initial estimates of the cost of a COVID-19 outbreak under seven different scenarios of how the disease has developed. The goal is not to be definitive about the outbreak of the virus, but rather to provide information on a range of potential economic costs of the disease (McKibbin \& Fernando (2020).

The Central Bank of Jordan issued a request to local banks to postpone the installments due on borrowers without bearing the interest of delay, and reducing interest rates on all monetary policy tools by 50 basis points, the sales tax entitlement has also been postponed until the amounts due on the catering, health, and pharmaceutical sectors are paid, in addition to allowing the listed companies, in what is known as the golden and silver lists, to pay $30 \%$ of the customs fees, provided that $70 \%$ of them will be paid later. Governmental decisions also included facilitating control procedures for entering goods such as medicine and food, whereas, March wages were disbursed to public sector employees and civilian and military retirees, for the purposes of ensuring the provision of cash liquidity to prevent leaving the house except for the necessary cases, to disable state institutions in the public and private sectors and to close the border crossings for two weeks (Al-Jazeera TV website, https://www.aljazeera.net/news/ebusiness/2020/4/29).

The Central Bank of Jordan pumped soft loans equivalent to approximately $\$ 700$ million "to enable small and medium universities to finance their expenses" and other measures aimed at ensuring job security for workers in many universities (interview with the Minister of Information, 3/4/2020).

\subsection{Corona Crisis Management}

\subsubsection{Corona Crisis Management}

A crisis is an unexpected event or chain of events that spins out of control and disrupts normal operations and thus threatens to damage the reputation of the organization. (Regester, 1995, Alsawalhah, 2014) .Crisis management refers to the system that is used to avoid emergency situations and how to deal with them when they occur in order to mitigate their devastating effects (Aktouf ,1992). It can be said that the crisis is an uncommon or expected situation that is beset with the uncertainty that leads to the disruption of the ordinary work of institutions, whether at the simple level or at the state level, and disrupts the interests of society and the economy (Reynolds, 2012) (Alomian, 2019) (Assaf, etal. 2013).

Because of these effects, organizational research from a variety of disciplines has devoted great attention to crisis management, working to understand why crises occur (Coombs \& Holladay, 2002) (Al-Raggad \& Alsawalhah, 2017), and how organizations can manage them to reduce harm (Bundy \& Pfarrer, 2015; Coombs, 2007; Kahn, Barton, \& Fellows, 2013)( Alsawalhah, 2020.

In an interview with the Jordanian Minister of State for Information Affairs: He mentioned that the state seeks to manage the "complex" crisis in an organized manner on the health, security, social, and economic levels ((Interview with the Minister of Information, 3/4/2020). The Jordanian government has developed several possibilities to address the challenges of the emergence of the Coronavirus and has prepared for all possibilities, and in comparison with the measures taken by the governments of the world, Jordan is considered to be at the forefront of the countries that have undertaken a series of proactive measures in anticipation of the outbreak of the disease, and these measures were necessary and provided by the vision of the Jordanian government. 
(Al-Kurdi, 2020). Jordan has developed a model of its own in managing the Corona crisis, as it did not seek to emulate the Chinese model, nor any other models, but rather followed its own path in crisis management, realizing that its political, economic, social and cultural system is different from other countries, it also knows that every country has comparative advantages that it uses to define the crisis management capabilities and modalities (Al-Maani, 2020). A number of observations on crisis management can be made by the countries of the world. (Suliman, 2020).

- The Corona crisis is a danger, anxiety, embarrassing and differential position that was accompanied by sharp changes, and affected the fate of entire societies, which necessitated the decision-maker to make decisions in the moment of the aggravation of the situation, and not before it reached the rest of the world.

- The Corona crisis was associated with a sense of danger and tension and the importance of the time component for taking decisions and confrontational measures, as it is considered a situation that needs to make an effort to learn about its variables and explain its phenomena and try to control its events and avoid its risks.

- The handling of the Corona crisis entailed several dimensions, the most important of which are: (1) Availability of in-depth insight into previous events to know the causes of the crisis and the circumstances that gave rise to it, and this is not clear to this moment, as there are numerous accounts of the cause of the virus outbreak, including its attribution of the quality of Chinese food, and another that America leaked gas in an experiment in Afghanistan, and not knowing the cause of the spread of this virus and is it really a virus or gas that would delay the access to treatment for it, (2) Having an open mind to realize all the dimensions surrounding the crisis: this matter is surrounded by ambiguity and it is not clear whether the decision-makers have sufficient information about this crisis or not? (3) A future vision to anticipate the developments that will happen, and this is also not clear in this crisis.

\subsubsection{Coronavirus Crisis Management Dimensions}

\section{Discover Early Warning Signs of Disease}

Although there are pre-indications of a possible crisis in the emergence of a virus in China, the response by the decision-maker was moderate, this is due to the lack of sufficient information for the decision-maker that there is a potential crisis that may affect the state, and then came the decision to isolate the cities and districts in which hotbeds of disease were spread, as happened with the city of Irbid, this means that the early warning system was of medium effectiveness, which enabled it to capture advance signals that enabled specialists to predict the probability of the direction of the crisis, to analyze the information available about it to develop the scenarios to deal with, by supporting decision-makers to make decisions, either by preventing their occurrence or reducing the potential effects of this crisis. (Roya website: https://royanews.tv/news/209517).

\section{Preparedness and Prevention to Face the Crisis}

The government has taken balanced measures through the Crisis Cell and implemented a strategy of proactive action in managing the crisis by preparing plans and capabilities to deal with the next steps, preparing for all possible scenarios, and not only facing the health consequences of the Corona epidemic, and laying down plans and taking measures and decisions to deal with other repercussions resulting from the epidemic, such as the economic, educational and social repercussions (Roya website, https://royanews.tv/news/210904).

\section{Containment of Damages}

Since the beginning of the crisis, the Jordanian government has taken many necessary decisions to confront the spread of the virus, the last of which was the deployment of Arab army forces at the entrances and exits of cities and governorates. All official and private institutions have been suspended, except for the vital sectors, citizens are obliged not to leave their homes except for necessity, with no movement between the governorates of the Kingdom, stopping mass transit, preventing the gathering of more than ten people, and stopping the printing of daily newspapers. This comes in addition to stopping medical reviews and operations except for the emergency ones while permitting the continuation of pharmacies, catering centers, bakeries, and food, drug, water, electricity, and fuel supply chains. The Jordanian government has started setting up quarantine camps on the land ports of Jordanians returning through them, with an emphasis on Jordanians abroad to remain in their places and follow the safety and Security and political measures determined by their host countries (Al-Jazeera website, https://www.aljazeera.net/news/politics/3/18/2020).

On March 25/2020, the government announced the opening of small groceries, basic foodstuff stores, vegetable and fruit shops, bakeries, pharmacies, and current water stores from 10:00 a.m. to 6:00 p.m. until further notice (Roya News website, https://royanews.tv/news/209517). 
The head of the International Monetary Fund's mission to Jordan, Christopher Jarvis, expected that the Jordanian economy will recover faster than other countries as a result of health and economic measures taken by the government to reduce the consequences of the Corona crisis. The Minister of Planning confirmed that the return of local economic activity would enable the pharmaceutical factories, sterilizers, and chemicals, in addition to agricultural business, to resume exporting abroad. For his part, Christopher Jarvis praised the Jordanian government's response quickly to contain the crisis, pointing out that Jordan's program and the International Monetary Fund are designed in a flexible manner that allows the use of some of the budget items to confront the Corona crisis, where some adjustments were made to the terms of the program to allow the government to spend more money on the health care sector, confronting financial costs in light of declining revenues in the current year (the Kingdom's website, https://www.almamlakatv.com/news/).

\section{Coordination with Other Countries in Combating the Disease}

The government benefited from the experiences of other countries that have proven successful in combating the disease and coordinated with it in exchanging information and data about the disease, particularly the experience of South Korea, laboratory examination to detect the virus through investigation teams in all governorates of the Kingdom and continuous and dynamic evaluation of the reality of the crisis and take appropriate measures with the situation, without panicking or losing balance through the Crisis Cell and Crisis Center and proactive movement in crisis management by preparing plans and capabilities to deal with the next steps and preparing for all possible scenarios, and not only to confront the health consequences of the Corona epidemic, and to develop plans and take measures and decisions to meet other consequences of the epidemic, such as the economic, educational and social repercussions (meeting with the Governor of the Jordan Bank, http://www.jsf.org/ar/content).

\section{The Methodology of the Study}

\subsection{Population of the Study and Its Sample}

The study followed the descriptive-analytical method in order to collect data from the sample of the study population. The study population consisted of (650) faculty members in Jordanian universities in the area of political sciences, media, and economics, a proportional stratified random sample of (270) faculty members was chosen, the study was conducted on (254) questionnaires that were valid for analysis, the sampling unit was targeted at faculty members at Jordanian universities.

\section{Statistical Analysis and Hypothesis Testing}

\subsection{Descriptive Analysis}

Table 1. Analysis of personal and employment data for the study sample

\begin{tabular}{cccc}
\hline Variable & & $\boldsymbol{N}$ & Percentage \\
\hline Gender & Male & 186 & $73 \%$ \\
& Female & 68 & $27 \%$ \\
Age & 30 years and less & 10 & $\% 4$ \\
& $30-40$ & 45 & $\% 18$ \\
& $41-50$ & 149 & $\% 58$ \\
Years of & 51 and more & 50 & $\% 20$ \\
experience & 5 years and less & 25 & $\% 10$ \\
& & & $\% 25$ \\
& $6-10$ years & 65 & $\% 48$ \\
& $11-15$ & 120 & $\% 17$ \\
\hline
\end{tabular}

From Table 1, it turns out that the percentage of males in these universities is much higher than that of females, where the percentage of males is $73 \%$, the highest age percentage was from $41-50$ years old when the rate was $58 \%$, and the highest percentage of years of experience was between $11-15$ years when the ratio reached $48 \%$. 


\subsection{Questionnaire Data Analysis}

Table 2. arithmetic averages and standard deviations for government measures and Corona crisis management

\begin{tabular}{|c|c|c|c|c|}
\hline $\begin{array}{c}\text { Items' } \\
\text { sequence }\end{array}$ & Dimension & Mean & $\begin{array}{l}\text { Standard } \\
\text { deviation }\end{array}$ & Rank \\
\hline $1-5$ & Health measures & 3.91 & 0.324 & High \\
\hline $10-6$ & Media measures & 3.45 & 0.532 & Moderate \\
\hline $15-11$ & $\begin{array}{c}\text { Security and } \\
\text { political measures }\end{array}$ & 4.45 & 0.285 & High \\
\hline $20-16$ & $\begin{array}{l}\text { Economic } \\
\text { measures }\end{array}$ & 3.31 & 0.211 & Moderate \\
\hline \multicolumn{2}{|c|}{$\begin{array}{c}\text { average of the government } \\
\text { measures' variable }\end{array}$} & 3.78 & & High \\
\hline $25-1$ & $\begin{array}{l}\text { The discovery of } \\
\text { early warning signs } \\
\text { of the disease }\end{array}$ & 4.01 & High & High \\
\hline $30-26$ & $\begin{array}{l}\text { Preparedness and } \\
\text { prevention to face } \\
\text { the crisis }\end{array}$ & 3.76 & High & High \\
\hline 35-31 & Contain the damage & 3.45 & 0.364 & Moderate \\
\hline $40-36$ & $\begin{array}{l}\text { Restore normal } \\
\text { activity (business } \\
\text { continuity) }\end{array}$ & 3.32 & 0.568 & Moderate \\
\hline $45-41$ & $\begin{array}{l}\text { Coordination with } \\
\text { other countries in } \\
\text { combating the } \\
\text { disease }\end{array}$ & 3.35 & 0.621 & Moderate \\
\hline Coronavir & Crisis Management & 3.58 & & Moderate \\
\hline
\end{tabular}

Table 2 shows the following:

Independent variable: government measures: The overall average for applying government measures from the viewpoint of faculty members in Jordanian universities was high, with an arithmetic average of (3.78).

Dependent variable: Corona Crisis Management: The overall average for managing the Corona crisis from the viewpoint of faculty members in Jordanian universities was moderate, with an arithmetic average of (3.58).

\subsection{Hypotheses Testing: For Hypothesis Testing, A Regression Method was Used}

Table 3. Model summary

\begin{tabular}{ccccc}
\hline St. Error & Adjusted $R^{2}$ & $R^{2}$ & $R$ & Model \\
\hline 0.185 & 0.494 & 0.506 & 0.712 & 1 \\
\hline
\end{tabular}


Table 4. ANOVA analysis of variance for the first main hypothesis

\begin{tabular}{cccccc}
\hline Sig & $\boldsymbol{F}$ & $\begin{array}{c}\text { Mean of } \\
\text { squares }\end{array}$ & $\boldsymbol{D f}$ & Sum of squares & Model \\
& & 1.713 & 1 & 1.713 & Regression \\
$\mathbf{0 . 0 0}$ & 61.581 & 252 & 2.817 & Residual value \\
& & 0.0071 & $\mathbf{2 5 3}$ & $\mathbf{4 . 5 2 0}$ & Total \\
\hline
\end{tabular}

Table 5. Coefficients table

\begin{tabular}{ccccc}
\hline Model & Standard error & $\begin{array}{c}\text { Beta } \\
\text { coefficients }\end{array}$ & $\begin{array}{c}\text { Calculated } \\
\text { value }(\boldsymbol{t})\end{array}$ & Sig \\
\hline Constant & 0.244 & - & 3.061 & $\mathbf{0 . 0 0 0}$ \\
Health measures & 0.079 & 0.421 & 10.125 & $\mathbf{0 . 0 0 0}$ \\
media measures & 0.085 & 0.289 & 8.567 & $\mathbf{0 . 0 0 0}$ \\
$\begin{array}{c}\text { Security and political } \\
\text { measures }\end{array}$ & 0.049 & 0.331 & 11.862 & $\mathbf{0 . 0 0 0}$ \\
Economic measures & $\mathbf{0 . 0 7 3}$ & $\mathbf{0 . 5 6 8}$ & $\mathbf{7 . 3 6 5}$ & $\mathbf{0 . 0 0 0}$ \\
\hline
\end{tabular}

The main hypothesis H01: There is no statistically significant effect at the level $(\alpha \leq 0.05)$ of government measures in its dimensions (health measures, media measures, Security and political measures, economic measures) on managing the Coronavirus crisis from the viewpoint of faculty members in Jordanian universities.

The test result was as follows:

From the Model summary table, it appears that there is a high correlation between government measures and the management of the Corona Virus Crisis, where the value of $\mathrm{R}=(0.712)$, as it was found that the value of $\mathrm{R} 2=$ (0.506), and this means that the independent variable government measures explain $50.6 \%$ of the variance in the dependent variable (Corona Virus Crisis Management), and from the table of analysis of variance (ANOVA) it is clear that the value of $\mathrm{F}$ has reached (61.851) at a confidence level $(\mathrm{Sig}=0.00)$ This confirms the significance of the slope at the level $(\alpha \leq 0.05)$ and at one degree of freedom $(\mathrm{df}=1.252)$. Accordingly, we reject the nihilistic hypothesis and accept the alternative hypothesis "There is a statistically significant effect at the significance level $(\alpha \leq 0.05)$ of government measures on the management of the Coronavirus crisis from the viewpoint of faculty members in Jordanian universities".

\section{Sub-hypothesis Testing}

The first sub- hypothesis H01-1:

There was no statistically significant effect at $(\alpha \leq 0.05)$ of the health measures on managing the Coronavirus crisis from the viewpoint of faculty members in Jordanian universities.

Referring to the coefficients table, it was found that the value of $(\mathrm{t})$ reached (10.125) at a confidence level (Sig= 0.00 ), as the value of Sig. is less than 0.05 we reject the null hypothesis and accept the alternative hypothesis "There is a statistically significant effect at the level of $(\alpha \leq 0.05 \alpha)$ of health measures on managing the Coronavirus crisis from the viewpoint of faculty members in Jordanian universities".

The second sub-hypothesis test: H01-2: There is no statistically significant effect at the level $(\leq 0.05 \alpha)$ of media measures on managing the Coronavirus crisis from the viewpoint of faculty members in Jordanian universities.

Referring to the coefficients table, it was found that the value of $(t)$ had reached (8.567) at a confidence level $(\mathrm{Sig}=0.00)$ and that the value of Sig. is less than $(0.05)$ we reject the null hypothesis and accept the alternative hypothesis "There is a statistically significant effect at the level of $(\alpha \leq 0.05)$ of media measures on managing the Coronavirus crisis from the viewpoint of faculty members in Jordanian universities".

Third hypothesis test: H01-3: There is no statistically significant effect at the level $(\alpha \leq 0.05)$ of Security and political measures on managing the Coronavirus crisis from the viewpoint of faculty members in Jordanian universities. 
Referring to the coefficients table, it was found that the value of $(t)$ had reached (11.862) at a confidence level $(\mathrm{Sig}=0.002)$ and that the value of Sig. is less than $(0.05)$ we reject the null hypothesis and accept the alternative hypothesis which states "There is a statistically significant effect at $(\boldsymbol{\alpha} \leq \mathbf{0 . 0 5})$ of the Security and political measures on the management of the Coronavirus crisis from the viewpoint of faculty members in Jordanian universities."

Fourth hypothesis test: H01-4: There is no statistically significant effect at the level of $(\alpha \leq 0.05)$ of economic measures on the management of the Coronavirus crisis from the viewpoint of faculty members in Jordanian universities.

Referring to the coefficients table, it was found that the value of $(t)$ had reached (7.365) at a confidence level $(\mathrm{Sig}=0.00)$ and that the value of Sig. is less than $(0.05)$, we reject the nihilistic hypothesis and accept the alternative that says "there is a statistically significant effect at the level of $(\alpha \leq 0.05)$ of economic measures on the management of the Coronavirus crisis from the viewpoint of faculty members in Jordanian universities."

\section{Findings and Recommendations}

\subsection{Findings}

- The application of government measures in light of the Corona crisis was high, and the security and health measures were highly ranked, while the economic and media measures were of a moderate degree.

- The level of corona crisis management came at a moderate degree in terms of level in general, and in detail, it happened after (discovering early warning signs of disease, preparedness, and prevention to face the crisis) at a high level while (containment of damage, restoration of normal activity (business continuity), Coordination with other countries in the fight against the disease came with a moderate degree.

- There is a statistically significant effect at the level of $(\alpha \leq 0.05)$ of government measures in its dimensions (health measures, media measures, Security and political measures, economic measures) on the management of the Coronavirus crisis from the viewpoint of faculty members in Jordanian universities.

- There is a statistically significant effect at the level of $(\alpha \leq 0.05)$ of health measures on managing the Coronavirus crisis from the viewpoint of faculty members in Jordanian universities.

- $\quad$ "There is a statistically significant effect at the level of $(\alpha \leq 0.05)$ of media measures on managing the Coronavirus crisis from the viewpoint of faculty members in Jordanian universities.

- There is a statistically significant effect at the level of $(\alpha \leq 0.05)$ of Security and political measures on managing the Coronavirus crisis from the viewpoint of faculty members in Jordanian universities.

- There is a statistically significant effect at the level of $(\alpha \leq 0.05)$ of economic measures on managing the Coronavirus crisis from the viewpoint of faculty members in Jordanian universities.

\subsection{Recommendations}

- Intensify health measures through preventive tracking teams for early detection of cases.

- $\quad$ The Security and political measures should not be at the expense of public freedoms.

- Developing comprehensive visual and written media programs to educate citizens about the risk of disease.

- Finding solutions to the current and expected economic problems due to the crisis, by issuing economic packages through the central bank related to financial and monetary policy in order to help the troubled sectors, and to involve the private sector in bearing the economic consequences of the disease.

- Stopping the movement of transport from outside the Kingdom, except for the most urgent need, and ensuring that all precautions are taken to prevent the transmission of infection.

- $\quad$ Providing all the required resources to the Ministry of Health, and enabling epidemiological investigation teams in the whole kingdom.

- Monitor the markets and the movement of commodities, and set indicative prices to prevent the exploitation of some merchants by citizens.

- $\quad$ Partially lifting the ban and expanding it, especially with cases remaining at zero.

- Cooperation with the countries of the region and the world in managing the crisis and exchanging information about patients and disease across borders. 


\section{References}

Alomian, N. (2019). The Impact of Strategic Intelligence on Achieving Competitive Advantage: Applied Study on the Pharmaceutical Companies Sector in Jordan. International Journal of Business and Social Science, 10(4). https://doi.org/10.30845/ijbss.v10n4p8

Al-Raggad, M. A. \& Alsawalhah, A. A. (2017). The impact of the strategies of resistance to change management on the improvement of workers performance (Case Study of the Jordanian Telecommunications Companies). Global Journal of Management \& Business Research, 17, 41-50. Retrieved from http://www.arpapress.com/Volumes/Vol30Issue2 /IJRRAS_30_2_02.pdf

Alsawalhah, A. (2014). Organization culture and its role in enhancing the competitive advantage (A Case Study of Jordan Hospital). Interdisciplinary Journal of Contemporary Research in Business, 6(1), 176-185.

Alsawalhah, A. (2020). Talent Management Strategy and its Impact on Employee's Development: An Empirical Study on Jordanian Pharmaceutical Companies. Modern Applied Science, 14(5), URL: https://doi.org/10.5539/mas.v14n5p75.

Assaf, A. \& Alsawalhah, A. (2013). Environmental impacts of working conditions in paint factories workers in the Hashemite Kingdom of Jordan. European Scientific Journal, 9(8).

Assaf, Abed-AlMutti A., Alsawalhah, A. \& Al-Tarawneh, H. (2013). The process of continuous development (improvement) and its effects on organizational performance in the department of lands and survey. European Scientific Journal, 9(13).

Aktouf, O. (1992). Management and Theories of Organizations in the 1990s: Toward A Critical Radical Humanism? Academy of Management.

Al-Abadi, M. (2020). Jordan formulates an inspiring experience in crisis management. Ammon Agency. https://www.ammonnews.net/article/525164

Al-Hawyan, A. (2020). National Security and Corona Crisis Management. on the Ammon Agency website, 4/18/2020: http://www.ammonnews.net/article/531363

Al-Kurdi, K. (2020). Jordan the strongest against Corona. the Jordanian newspaper Al-Ghad dated 7/4/2020, https://alghad.com.

Al-Maani, M. (2020). Distinguished Jordan Model in the Face of the Corona Crisis. Ammon Website, 4/14/2020. https://www.ammonnews.net/article/530637

Al-Zubaidi, N. (2010). The United States of America and its Management of International Crises: An Analytical and Applied Study. Doctorate of Philosophy Degree in Political Science, Clements.st International University, Baghdad, Iraq.

Brooks, S., Webster, R., Smith, L., Woodland, L., Wessely, S. \& Greenberg, N. (2020). The psychological impact of quarantine and how to reduce it: a rapid review of the evidence. Lancet, 2020, 395-912-20.

Bundy, J. \& Pfarrer, M. D. (2015). A burden of responsibility: The role of social approval at the onset of a crisis. Academy of Management Review, 40, 345-369.

Chen, S., Yang, J., Yang, W., Wang, C. \& Bärnighausen, T. (2020). COVID-19 control in China during mass population movements at New Year. Lancet, 2020, 395-764 -6. https://doi.org/10.1016/ S0140-6736(20)30421-9.

Coombs, W. T. (2007). Protecting organization reputations during a crisis: The development and application of situational crisis communication theory. Corporate Reputation Review, 10, 163-176

Coombs, W. T. \& Holladay, S. J. (2002). Helping crisis managers protect reputational assets. Management Communication Quarterly, 16, 165-186.

Interview with the Minister of Information. (2020). (3/4/2020) https://www.mc-doualiya.com/chronicles.

Kahn, W. A., Barton, M. A. \& Fellows, S. (2013). Organizational crises and the disturbance of relational systems. Academy of Management Review, 38, 377-396.

National Shield Magazine (2020). Media in the Crisis Corona Virus Model. nationshield.ae /index.php/home/details/research

Regester.M. (1995). The Practice of Public Relations, edited by Sam Black. 4th.ed. Butterworth-Heinemann, Oxford. 
Reynolds.B. (2012). Crisis and Emergency Risk: Communication Centre for Disease Control andPrevention. Wayne State University.

Suliman, S. (2020). Coron Crisis and Early Warning to Nations. The Egyptian Center for Thought and Strategic Studies, (https://covid-19.ecsstudies.com/5308/)

The Novel Coronavirus Pneumonia Emergency Response Epidemiology Team. (2020). The epidemiological characteristics of an outbreak of 2019 novel coronavirus diseases (COVID-19)—China. 2020. China CDC Weekly. 2020; 2:113-22.

\section{Copyrights}

Copyright for this article is retained by the author(s), with first publication rights granted to the journal.

This is an open-access article distributed under the terms and conditions of the Creative Commons Attribution license (http://creativecommons.org/licenses/by/3.0/). 